\title{
GIS-based Remote Sensing Analysis and Disaster Pre-warning Method of Complicated Geologic Structure in Highway Corridor Zone
}

\author{
Hao Lei ${ }^{1}$, Junling Qiu ${ }^{2, *}$, Jinxing Lai ${ }^{2}$ and Xiuling Wang ${ }^{2}$ \\ ${ }^{1}$ Institute of Geotechnical Engineering, Xi'an University of Technology, Xi'an 710048, China \\ ${ }^{2}$ School of Highway, Chang'an University, Xi'an 710064, China \\ ${ }^{*}$ Corresponding author
}

\begin{abstract}
In order to realize the efficient organization of the engineering geological information, the GIS management platform was proposed, which can realize the comprehensive management of RS interpretation results and GPS positioning. Based on a highway, the management pattern of multi-source, multi-date and multi-resolution image data was adopt. Moreover, the fast display and overlapping display of vector data and image data as well as the integrated management of image data were employed. Meanwhile, comprehensive analysis and dynamic management of engineering geological conditions of the corridor zone along the highway were implemented.
\end{abstract}

Keywords-highway; corridor zone; unfavorable geology; remote sensing interpretation; GIS management pre-warning

\section{INTRODUCTION}

Within the corridor zone along the highway, the unfavorable geology, including landslide, collapse, debris flow, etc., have the direct influence on disaster of the line selection for highway construction in earlier stage and operation period, which will cause destructive geological effect to human life and property and survival environment. Generally, the investigation on unfavorable geology in highway construction mainly focuses on the engineering feasibility study stage of highway design. Moreover, the field reconnaissance and drilling are mainly employed. However, these traditional methods have limitations for unfavorable geology with complicated regional environment and a wide range. With the sustainable development and perfection of geographic information and remote sensing (RS) technology, the remote sensing technology has been applied to the risk evaluation of geological hazards, which can provide scientific basis for the establishment of disaster prevention and reduction plan and the deployment of control engineering [1]. Therefore, the application of remote sensing technology is the inevitable trend for investigation and evaluation of highway geological hazards [2].

China is one of the countries with serious geological hazards, and the loss induced by geological hazards accounts for over 20 percent of the total loss induced by natural disasters every year, which brings great threat to the safety of people's life and property. Based on a highway, the management pattern of multi-source, multi-date and multi-resolution image data is adopt. Also, the fast display and overlapping display of vector data and image data as well as the integrated management of image data are employed. Meanwhile, comprehensive analysis and dynamic management of engineering geological conditions of the corridor zone along the highway are implemented, which can provide scientific and reasonable basis for the construction of highway engineering.

\section{GeOlOGY AND GeOMORPHOLOGY OVERVIEW}

The engineering area is located in the transition zone of northwest boundary between Sichuan Basin and Qinghai-Tibet Plateau. The west area of Maowen fracture is Xiaojin arc folded zone, and the east area is the Longmen Mountain Cathaysian structural system. Furthermore, Maowen fracture and Yingxiu fracture are two main fractures in this working area, both of which are active fractures. Particularly, the " 5.12 large earthquake” had occurred in Yingxiu fracture, as shown in figure 1. Due to the influence of the earthquake, surface rock mass of mountains was broke in the study area, so geological hazards, such as collapse, landslide, debris flow, etc., may seriously affect the highway construction [3]. Meanwhile, it is difficult to explore the study area manually because of the dense vegetation and complicated conditions. On August 14, 2010, large scale flush flood and debris flow attacked the whole study area, which greatly damaged the highway system that was reconstructed after the large earthquake in Wenchuan.

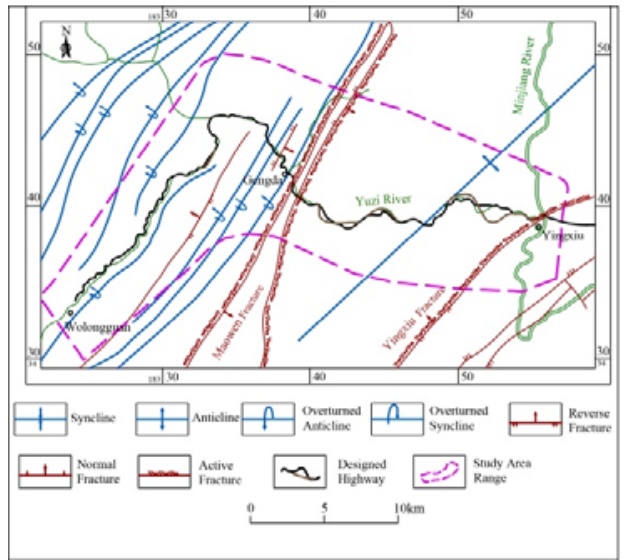

FIGURE I. ROUTE DISTRIBUTION AND GEOLOGICAL STRUCTURE 


\section{INFORMATION COLLECTION AND PROCESSING}

\section{A. Information Collection}

Currently, the common remote sensing images mainly include ETM image, ALOS image, Quick Bird image, World View image, Radar image, etc. With the development of science and technology, resolution of remote sensing image has been greatly improved. In the practical project, selection of remote sensing images should meet the specific requirements. Experiences show that the minimum size for recognized target on images should be equal to 5-10 times of the ground resolution, meanwhile, the identification of single target should be covered at least $10 \times 10$ pixels.

1) Selection of remote sensing information source: Considering the accuracy requirement, remote sensing images with better reflection of provincial characteristics, wide coverage and strong practicability were selected as the basic data, they were Quick Bird (QB) remote sensing data on May 30, 2008 and World View-2 (WV-2) remote sensing data on December 10, 2010. These panchromatic images with resolutions of $0.61 \mathrm{~m}$ and $1.84 \mathrm{~m}$, respectively, can meet the highway resolution requirement.

2) Other information: 1:50,000 topographic map: DEM data and administrative map of the area were collected. Furthermore, 968 GPS point coordinates within the study area were obtained through field investigation, of which 848 points belonged to typical unfavorable geology.

\section{B. Data Processing}

1) Image processing and information extraction: Remote sensing images were processed using ERDAS8.7 platform. (1) Based on the decimeter control points and DEM data collected through RBN/DGPS, data pre-processing, including band infusion, geometric precise correction, radiation correction, tessellation, etc., was performed. (2) Through the adjustment of bands, band combination with the best recognition of unfavorable geology was obtained on the basis of the enhancement of remote sensing images. (3) The accuracy of planar positioning of corrected images should be better than $\pm 5 \mathrm{~m}$, meanwhile, longitude-latitude projection was employed to establish a unified coordinate system [4].

After processing above, the remote sensing images would be more uniform in colors. The vegetation, landform, river system, formation lithology, and micro-geomorphic features were reflected more clearly, which significantly improved the accuracy and correctness of the judgment of remote sensing geology. Besides, the dynamic change information of unfavorable geology in different periods was obtained [5]. Results are shown in figures 2 and $3 . \mathrm{H}, \mathrm{B}, \mathrm{N}$ and $\mathrm{K}$ in figures refer to landslide, collapse, debris flow and mileage stake mark, respectively. The number behind the letter refers to the corresponding serial number.

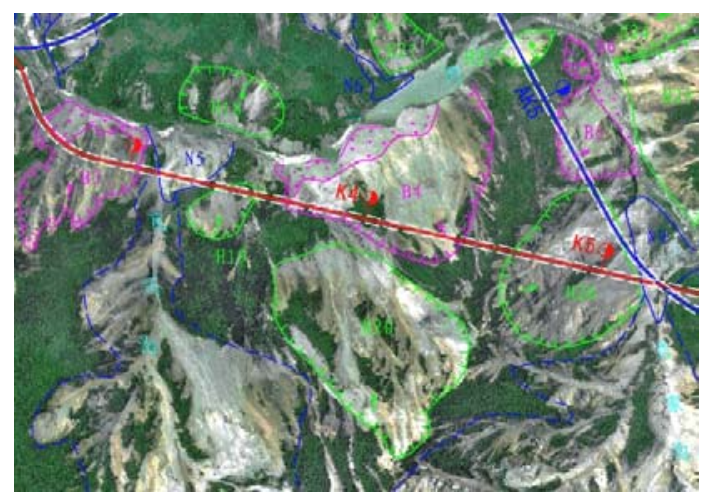

FIGURE II. REMOTE SENSING INTERPRETATION AND COMPILATION MAP OF QB ON MAY 2012

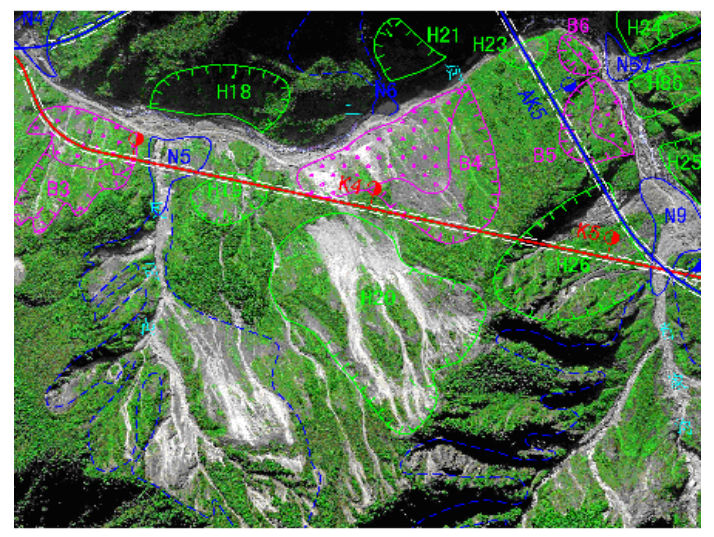

FIGURE III. REMOTE SENSING INTERPRETATION AND COMPILATION MAP OF WV-2 ON DECEMBER 2014

2) Information integration and management: The remote sensing images of two phases were interpreted employing the supervised classification method, and then spatial database and attribute database for disaster were established through visual interpretation and calibration to obtain the classification results [6]. Moreover, the classification results of two phases were revised through man-computer interaction. Combined with the GIS technology, the spatial analysis module in Arc/Info was applied to calculate the unfavorable geologic area range of two phases, and then DEM data were used to extract the gradient and area change of each unfavorable geological structure as well as algebraic operation information of maps. Finally, changes can be analyzed by overlaying images of two phases. The structure of highway database in study area is shown in Table 1.

TABLE I. STRUCTURE OF HIGHWAY DATABASE BASED ON GIS

\begin{tabular}{ccccc}
\hline \multicolumn{1}{c}{ Field name } & Glma & Glmb & Length & Glmc \\
\hline $\begin{array}{l}\text { Definition of field } \\
\text { name }\end{array}$ & Highway name & Number & Length & Grade \\
\hline
\end{tabular}

\section{REMOTE SENSING INTERPRETATION OF UNFAVORABLE} GEOLOGY

As the key contents for geological remote sensing survey and highway engineering evaluation, landslide, collapse, debris flow and other geological disasters have serious effects on the 
quality and safety of rotes. The active structure affects the regional stability, which directly determines the highway route alignment.

Any unfavorable geology occurred can leave deformation indication on the geomorphologic shape. On the basis of the indication spectrum (tone), shadow and geometrical morphological characteristics, the boundary range can be determined. Also, the disaster types can be identified well. The recognition of geological disaster is depend mainly on the spatial structural information of images, including the shape, size, texture (shadow pattern), as well as the spectral information of images. After the combination of stratum rock, microtopography, vegetation, river system, landscape, and so on, the interpretation of geological disasters is established.

\section{A. Landslide}

Based on the geological structure, lithological association and geomorphic features of this area, the features of the landslide include plane shape, image landmarks, and geomorphic features.

\section{B. Collapse}

There are high mountains and deep valleys in this area, thus the topography is much precipitous. River lateral erosion for the slope toe and free surface due to human activity provide the spatial and background conditions of collapse. Collapse wall and avalanche debris cone are usually caused by strong earthquake, frequent intensive and short-time rainstorm in summer, as well as other unfavorable factors, sometimes these factors occur in coincidence.

\section{Debris Flow}

According to the appearance form, debris flow can be mainly divided into two types, which are: valley debris flow and slope debris flow. Valley debris flow is composed of formation area, flowing area and accumulation area, which forms an obvious interpretation mark on the remote sensing image. According to the activity cycle, debris flow is mainly divided into two types, which are: active debris flow and intermittent debris flow. Active debris flow cause tremendous hazards to highways operation. More specifically, the main characters of active debris flow and intermittent debris flow are shown in Table 2.

TABLE II. DISTINCTION AND INTERPRETATION OF ACTIVE DEBRIS FLOW AND INTERMITTENT DEBRIS FLOW

\begin{tabular}{|c|c|c|}
\hline $\begin{array}{c}\text { Debris } \\
\text { flow area }\end{array}$ & Active debris flow & Intermittent debris flow \\
\hline $\begin{array}{l}\text { Forn } \\
\mathrm{n} \text { are }\end{array}$ & $\begin{array}{ll}\text { Bare slope } & \text { surface; } \\
\text { Abundant loose } & \text { materials; } \\
\text { Occurring } & \text { landslide, } \\
\text { collapse, and gully }\end{array}$ & $\begin{array}{lr}\text { Rich vegetation; } & \text { Less loose } \\
\text { materials; } & \text { Occurring } \\
\text { small-scale } & \text { unfavorable } \\
\text { geological hazards }\end{array}$ \\
\hline Flow & $\begin{array}{l}\text { Straight and steep gully } \\
\text { bed }\end{array}$ & $\begin{array}{l}\text { Having the nature of river } \\
\text { valley; Gentle longitudinal } \\
\text { slope }\end{array}$ \\
\hline $\begin{array}{l}\text { Acc } \\
\text { tion }\end{array}$ & $\begin{array}{l}\text { Light-colored; Covering } \\
\text { new debris flow; } \\
\text { Sheetflood on fan-shaped } \\
\text { area without fixed groove; } \\
\text { Less vegetation }\end{array}$ & $\begin{array}{l}\text { Dark-colored; Fixed groove } \\
\text { on fan-shaped area without } \\
\text { sheetflood; Scarp resulting } \\
\text { from river erosion in front of } \\
\text { the fan-shaped area with } \\
\text { vegetation or cultivated land } \\
\text { and buildings }\end{array}$ \\
\hline
\end{tabular}

\section{GIS MANAGEMENT}

\section{A. Engineering Geological Zoning}

According to characteristics of highway engineering, engineering geology is zoned on the basis of geomorphologic units, geological structure, petrofabric characteristics of engineering geology, and unfavorable geology development degree. Second-level zoning is conducted in the study area with 3 engineering geological zones and 5 geological sub-zones, as shown in Table 3.

\section{TABLE III. ENGINEERING GEOLOGICAL ZONING}

\begin{tabular}{|c|c|c|}
\hline $\begin{array}{c}\text { Engineering } \\
\text { geological zone }\end{array}$ & $\begin{array}{c}\text { Engineering geological } \\
\text { sub-zone }\end{array}$ & Distribution \\
\hline $\begin{array}{l}\text { Engineering } \\
\text { geological zone } \\
\text { I - Valley }\end{array}$ & $\begin{array}{l}\text { Engineering } \\
\text { sub-zone for loose rock } \\
\text { group }\left(\mathrm{I}_{1}\right)\end{array}$ & $\begin{array}{l}\text { Minjiang valley and } \\
\text { Yuzixi valley terrace }\end{array}$ \\
\hline $\begin{array}{l}\text { Engineering } \\
\text { geological zone }\end{array}$ & $\begin{array}{lr}\text { Middle mountain } & \text { meological } \\
\text { engineering } & \text { georick } \\
\text { sub-zone for semi-hard rock } & \left.\text { and hard rock, and shale ( } \mathrm{II}_{1}\right)\end{array}$ & South of Yingxiu, \\
\hline $\begin{array}{l}\text { II - Middle } \\
\text { mountain }\end{array}$ & $\begin{array}{l}\text { Middle mountain } \\
\text { engineering geological } \\
\text { sub-zone for hard carbonate } \\
\text { rock }\left(\mathrm{II}_{2}\right)\end{array}$ & \\
\hline $\begin{array}{l}\text { Engineering } \\
\text { geological zone } \\
\text { III - High } \\
\text { mountain }\end{array}$ & $\begin{array}{l}\text { High mountain engineering } \\
\text { geological sub-zone for hard } \\
\left.\text { intrusive rock (III }{ }_{1}\right) \\
\text { High mountain engineering } \\
\text { geological sub-zone for } \\
\text { semi-hard and hard } \\
\text { metamorphic rock with } \\
\left.\text { carbonate rock ( } \mathrm{III}_{2}\right)\end{array}$ & $\begin{array}{l}\text { Yingxiu-Gengda } \\
\text { section, with large } \\
\text { area }\end{array}$ \\
\hline
\end{tabular}

\section{B. Unfavorable Geology Management}

- Classification and comparison of two-phase unfavorable geological bodies

Data was collected from the remote sensing images in 2008. Landslide, collapse, debris flow and other unfavorable geological phenomena were induced by "5.12" Wenchuan Earthquake. Subsequently, unfavorable geological phenomena occurred near the earthquake epicenter (Yingxiu) with the banding and flake distribution. For the Gengda-Wolong section, which was far from the earthquake epicenter, the geological hazards sporadically happened on the road side-slopes on a small scale. According to the remote sensing images in 2010, the unfavorable geological bodies changed greatly compared with the remote sensing images in 2008, as shown in Table 4. Meanwhile, statistical results for two-phase unfavorable geological bodies in remote sensing images are shown in Table 5.

TABLE IV. CHANGES OF UNFAVORABLE GEOLOGICAL BODIES

\begin{tabular}{lll}
\hline Classification & \multicolumn{1}{c}{ Change situation } & \multicolumn{1}{c}{$\begin{array}{c}\text { Typical } \\
\text { example }\end{array}$} \\
\hline Landslide & $\begin{array}{l}\text { Expansion of landslide area } \\
\text { Collapse }\end{array}$ & $\begin{array}{l}\text { Great increase of collapse body volume } \\
\text { B4 }\end{array}$ \\
Debris flow & $\begin{array}{l}\text { Significant increase of accumulation } \\
\text { body volume }\end{array}$ & N5 \\
\hline
\end{tabular}


TABLE V. STATISTICS FOR UNFAVORABLE GEOLOGY

\begin{tabular}{ccclc}
\hline $\begin{array}{c}\text { The } \\
\text { year }\end{array}$ & $\begin{array}{c}\text { Collapse } \\
\text { quantity }\end{array}$ & $\begin{array}{c}\text { Landslide } \\
\text { quantity }\end{array}$ & $\begin{array}{c}\text { Debris flow } \\
\text { quantity }\end{array}$ \\
\hline 2008 & 41 & 75 & 50 & \\
2010 & 44 & 86 & 64 & \\
\hline
\end{tabular}

\section{Qualitative Analysis of the Unfavorable GEOLOGY INFORMATION}

Considering the significant traffic position and frequent geological hazards in the study area, the unfavorable geology, including collapse, landslide, debris flow, etc., was monitored and controlled to avoid the traffic congestion through the GIS-based dynamic management platform. More specifically, in order to realize the geological hazard pre-warning, the development condition of typical unfavorable geology should be monitored dynamically. For the vital area, on-site investigation could be conducted by employing the GPS high precision positioning system.

In 2008, the remote sensing image presented the collapse with length of $650 \mathrm{~m}$, width of $80 \mathrm{~m}$ and collapsed volume of $3.1 \times 105 \mathrm{~m}^{3}$, whereas the remote sensing image indicated the collapse with length of $680 \mathrm{~m}$, width of $120 \mathrm{~m}$ and collapsed volume of $4.2 \times 105 \mathrm{~m}^{3}$ in 2010 . And, apparently, the collapse area enlarged, but the vegetation on this collapse recovered to some extent. Through the on-site investigation, the supporting scheme was proposed in consideration of line design scheme, size, specification and influenced scope of B4 collapse. As shown in Table 6. It can be seen that the coincidence degree of unfavorable geology information is $93 \%$ in 2008, and the coincidence degree is $89 \%$ in 2010, which meets the requirement of highway engineering construction.

TABLE VI. INFORMATION EXTRACTION OF UNFAVORABLE GEOLOGICAL CONDITIONS

\begin{tabular}{|c|c|c|c|c|c|c|c|}
\hline \multirow[b]{2}{*}{$\begin{array}{l}\text { The } \\
\text { year }\end{array}$} & \multicolumn{2}{|c|}{ Collapse } & \multicolumn{2}{|r|}{ Landslide } & \multicolumn{2}{|r|}{ Debris flow } & \multirow{2}{*}{$\begin{array}{c}\text { Coincidence degree } \\
(\%)\end{array}$} \\
\hline & $\begin{array}{c}\text { Information } \\
\text { extraction }\end{array}$ & $\begin{array}{c}\text { On-site } \\
\text { investigation }\end{array}$ & $\begin{array}{c}\text { Information } \\
\text { extraction }\end{array}$ & $\begin{array}{c}\text { On-site } \\
\text { investigation }\end{array}$ & $\begin{array}{c}\text { Information } \\
\text { extraction }\end{array}$ & $\begin{array}{c}\text { On-site } \\
\text { investigation }\end{array}$ & \\
\hline 2008 & 41 & 48 & 75 & 79 & 50 & 51 & 93 \\
\hline 2010 & 44 & 56 & 86 & 94 & 64 & 66 & 89 \\
\hline
\end{tabular}

\section{CONCLUSIONS}

- The GIS-based dynamic management platform can realize organization and management of image data with multi-source, multi-temporal and multi-resolution. Meanwhile, the efficient organization of highway engineering geological information can be guaranteed through the fast overlay displaying of vector data and image data, as well as integration and contrastive analysis of image data.

- Compared with the on-site investigation, the information extracted by GIS has the high accuracy of $89 \%$, which meets the requirement of highway engineering construction. And the GIS-based dynamic management platform can obtain more effective information. Furthermore, the dynamic management of unfavorable geology is realized.

- GIS has been successfully applied in the disaster pre-warning for complicated geologic structure in highway corridor zone. The GIS-based dynamic management platform, however, cannot completely replace the basic data collection, on-site investigation and experimental analysis. Instead, the GIS-based remote sensing analysis should be based on the deeply understanding of occurrence mechanism and geological condition of unfavorable geology.

\section{REFERENCES}

[1] E. Bedini, "Mineral mapping in the Kap Simpson complex, central East Greenland, using HyMap and ASTER remote sensing data”, Advances in Space Research, vol. 47, no. 1, pp. 60-73, 2011.

[2] Z.Y. Dong, Z.M. Wang and D.W. Liu, “Assessment of habitat suitability for waterbirds in the West Songnen plain, China, using remote sensing and GIS”, Ecological Engineering, vol. 55, pp. 94-100, 2013.

[3] D.R. Kniveton, P.J. DeGraff and K. Granica, "The development of a remote sensing based technique to predict debris flow triggering conditions in the French Alps”, International Journal of Remote Sensing, vol. 21, no. 3, pp. 419-434, 2000.

[4] Matti Mõttus and Tuure Takala, “A forestry GIS-based study on evaluating the potential of imaging spectroscopy in mapping forest land fertility”, International Journal of Applied Earth Observation and Geoinformation, vol. 33, pp. 302-311, 2014.

[5] F. Mantovani, R. Soeters and C.J. VanWesten, "Remote sensing techniques for landslide studies and hazard zonation in Europe," Geomorphology, vol. 15, no. 3-4, pp. 213-225, 1996.

[6] J.X. Lai, J.L. Qiu, J.X. Chen, Y.Q. Wang and H.B. Fan, “Application of wireless intelligent control system for HPS lamps and LEDs combined illumination in road tunnel", Computational Intelligence and Neuroscience, vol. 2014, Article ID 429657, 7 pages, 2014. 